\title{
Olivier Delsaux, La mise en prose des 'Vigiles des morts' de Pierre de Nesson, texte inconnu attribuable à Jean Miélot
}

\section{Maria Colombo Timelli}

\section{(2) OpenEdition \\ 1 Journals}

\section{Édition électronique}

URL : http://journals.openedition.org/studifrancesi/2099

DOI : 10.4000/studifrancesi.2099

ISSN : 2421-5856

Éditeur

Rosenberg \& Sellier

Édition imprimée

Date de publication : 1 avril 2014

Pagination : 125

ISSN : 0039-2944

\section{Référence électronique}

Maria Colombo Timelli, «Olivier Delsaux, La mise en prose des 'Vigiles des morts' de Pierre de Nesson, texte inconnu attribuable à Jean Miélot », Studi Francesi [En ligne], 172 (LVIII | I) | 2014, mis en ligne le 01 avril 2014, consulté le 18 septembre 2020. URL : http://journals.openedition.org/studifrancesi/2099 ; DOI : https://doi.org/10.4000/studifrancesi.2099

Ce document a été généré automatiquement le 18 septembre 2020.

\section{cc) $($ ) $\ominus$}

Studi Francesi è distribuita con Licenza Creative Commons Attribuzione - Non commerciale - Non opere derivate 4.0 Internazionale. 


\title{
Olivier Delsaux, La mise en prose des 'Vigiles des morts' de Pierre de Nesson, texte inconnu attribuable à Jean Miélot
}

\author{
Maria Colombo Timelli
}

\section{RÉFÉRENCE}

OLIVIER DELSAUX, La mise en prose des 'Vigiles des morts' de Pierre de Nesson, texte inconnu attribuable à Jean Miélot, «Le Moyen Âge», CXIX/1, 2013, pp. 143-181.

1 La «mise en prose» étudiée ici par O.D. présente plusieurs traits saillants. En premier lieu, il s'agit d'un texte quasiment inconnu de la critique; en outre, il s'agit de la réécriture d'un texte appartenant à l'office des morts, qui se situe donc en dehors des adaptations en prose des genres littéraires 'classiques', chansons de geste et romans; enfin, Jean Miélot a rédigé son texte moins de dix ans après la mort présumée de Pierre de Nesson, ce qui impose de chercher ailleurs que dans l'évolution linguistique la raison de sa réécriture. O.D. décrit d'abord le manuscrit unique (Bruxelles, KBR, 11035-37, appartenu à Philippe le Bon), pour passer ensuite à la question de l'attribution du texte: à ses yeux, le «secrétaire» de Philippe le Bon est à la fois le copiste et l'auteur de la «prose». La section la plus importante de cet article porte sur la technique de réécriture, analysée dans les moindres détails: fidèle à la source en vers, Miélot s'efforce néanmoins de produire un texte plus clair, plus linéaire et moins redondant. Surtout, il intervient parfois sur son modèle pour le corriger, en ayant recours directement aux Lamentations de Job, source de Pierre de Nesson. Parmi les conclusions tirées par O.D. retenons en particulier la confirmation du fait que le travail intellectuel que Jean Miélot effectuait pour le Duc de Bourgogne se doublait d'une dimension matérielle qu'il est impossible d'ignorer. 